AGRICULTURE AND BIOLOGY JOURNAL OF NORTH AMERICA

ISSN Print: 2151-7517, ISSN Online: 2151-7525, doi:10.5251/abjna.2012.3.5.213.220

(C) 2012, ScienceHuß, http://www.scihub.org/ABJNA

\title{
Production of Gliricidia and Leucaena - based multi-nutrient blocks as supplementary ruminant feed resource in South Western Nigeria
}

\author{
Aye P. A \\ Animal Production and Health Sciences Department \\ Ekiti State University Ado-Ekiti, Nigeria \\ amokapius@yahoo.com
}

\begin{abstract}
The energy, protein and minerals contained in agricultural wastes can be made available for feed supplementation of ruminants through production of multinutrient blocks (MNBs). Fibrous residues obtained from leaf protein concentrate of Leucaena leucocephala and Gliricidia sepium leaves fractionation were used to produce MNBs as follows: Leucaena + Poultry manure (LPMNB); Leucaena + Urea + Poultry manure (LUPMNB); Leucaena + Urea (LUMNB); Gliricidia + poultry manure (GPMNB); Gliricidia + Urea + poultry manure (GUPMNB) and Gliricidia + Urea (GUMNB). The proximate analysis and energy contents of multinutrient blocks (MNBs) showed that GUMNB contained the highest crude protein while GPMNB contained the least. The ash content was least in LPMNB and highest in GPMNB while LUMMB contained the least crude fibre but highest in GUPMNB. The ether extract values were 44.1 $\pm 0.01,65.1 \pm 0.01,70.2 \pm 0.01$, $81.9 \pm 0.01,91.1 \pm 0.15 \mathrm{~g} \mathrm{~kg}^{-1}$ for LUMNB, LPMNB, LUPMNB, GPMNB, GUPM̄NB, respectively while the nitrogen free extract (NFE) values varied from $247.3 \pm 1.11 \mathrm{~g} \mathrm{~kg}^{-1} \mathrm{DM}$ in GUMNB to $523.8 \pm 6.28 \mathrm{~g} \mathrm{~kg}^{-1} \mathrm{DM}$ in LPMNB. The gross energy (GE) contents for GPMNB, LPMNB, LUPMNB, GUPMNB, LUMNB, GUMNB were 11.67, 12.74, 13.58, 14.56, 15.33, $15.48 \mathrm{MJ} \mathrm{kg}^{-1}$ respectively.Calcium was the most abundant $\left(737.50 \mathrm{~g} \mathrm{~kg}^{-1}\right.$ to $\left.971.40 \mathrm{~g} \mathrm{~kg}^{-1}\right)$ but the values were higher in Leucaena-based MNBS. The anti-nutrients of the multinutrient blocks are total polyphenols (as tannic acid equivalent), Phytin-P and oxalate.
\end{abstract}

Keywords : Nutrient composition, Anti- nutrients, Multinutrient, Poultry manure,Urea.

\section{INTRODUCTION}

One of the major problems confronting ruminant producers in many tropical countries is the scarcity of suitable basal energy feeds that arises from the inadequate production of these feed sources and competing uses by man. The rising food prices have worsened the situation such that the search continues for cheaper and substitutes whose consumption would not adversely affect the performance of animals.

Rearing of sheep and goats,especially is hampered by the seasonal availability of good quality and quantity of feeds such that during the dry season months, the little available forage is of low quality. The consequences are weight losses, low birth weight, lowered resistance to disease and reduced animal performance (Fajemisin et al., 2010). This, therefore, calls for a reasonable level of feed supplementation, with agro-industrial by-products which are cheap and can supply substantial amounts of livestock energy, protein and mineral needs.

Maximum benefits can be obtained from agricultural/agro-industrial by-products as feeds when supplementation promotes the efficiency of rumen microbial growth and supplies the animals with sufficient by-pass nutrients to balance nutrient availability and nutrient demand (Preston and Leng, 1987; Leng et al, 1991;Aletor et al.,2010). Molasses, urea and poultry manure contain available energy, nitrogen $(\mathrm{N})$ and minerals and are used in feeding ruminant animals (Preston and Leng, 1990). Pickstock (1985) observed that in times of drought when energy and protein reserves of animals fall to dangerously low levels, feeding of molassesurea/poultry manure mixtures satisfies the energy and protein needs for maintenance of ruminants. A means of presenting these feed sources is multinutrient blocks which will upgrade the energy and ammonia levels in the rumen (Mancini et al., 1997). The amount of energy supplied concurrently by 
ruminal carbohydrate degradation dictates the extent to which urea can be utilized for microbial protein synthesis (Hadjipanayiotu et al., 1993)

The main justification for using feed blocks to provide deficient nutrients is the convenience for packaging, storage, transport and ease of feeding. The use cement and molasses as binders ensures the slow release of the otherwise toxic molasses and urea (Onwuka, 1997). The choice of ingredients used for making multi-nutrient blocks will depend on availability, nutritive value, price, ease of handling and the effect on quality of the blocks (Leng and Kunju, 1989). A wide range of ingredients can be used: molasses, urea, poultry manure and waste, fibrous residues from leaf fractionation, bran (rice, wheat or maize), oilseed meals, and cakes (soyabean, coconut, groundnut, cotton seed, olive), agro-industrial by-products and miscellaneous nonconventional feeds (sugar beet pulp, citrus pulp, tomato pulp, cassava waste, milled groundnut shells, brewers grain, bagasse and slaughter house offals), cement or lime, salt and/or minerals (Kunjus,1986).

Report showed that molasses will provide a range of minerals (except phosphorus, P) and a complete mixture of vitamins, and will make blocks appetising for animals (Sancoucy 1996). Urea provides the small amount of extra $\mathrm{N}$ required for utilization of the dry matter in addition to that present in normal dry season forages and to maintain the ammonia level in the rumen, at a constant and sufficient amount for better development of the micro-organisms, leading to better degradation of the cellulosic components (Preston and Leng, 1987). The fibrous components are high in $\mathrm{P}$, trace minerals and a range of vitamins. They absorb moisture from the molasses and give structure to the blocks. Cement or quicklime is used as binding agent. Studies in USA, USSR and Canada have shown no negative effects, over long periods of time, when cement constitutes up to $1.5 \%$ of the total daily intake of dry matter (Sansoucy and Aarts, 1986; Onwuka, 1999; Adegbola, 2002). Salt provides much of the macro minerals (sodium, potassium, calcium and phosphorus) requirements of the microbes as well as those of the host animals. Multi-nutrient blocks, therefore, provide the nutrient requirements of both the microbes and the host animal.

Some information is available on the nutritive value of multi-nutrient blocks made from farm wastes (Sansoucy, 1986), but there is none on the nutritive value of Gliricidia and Leucaena based multinutrient blocks. This study was therefore undertaken on the design and production of low-cost, high quality feed supplements that will be adopted by ruminant farmers especially for dry season feeding to improve the performance of sheep and goats.

\section{MATERIALS AND METHODS}

Fibrous Residue Production: Fresh Gliricidia sepium and Leucaena leucocephala leaves were harvested from the Teaching and Research Farm of Ekiti State University, Ado-Ekiti. The leaves were washed, pulped and pressed with a screw-press as described by Aye (2007). The leaf juice was separated by filtering through pillow cases with a screw-press. The fibrous residue (FR) was then pulverized and spread in the sun to dry, and kept in air tight containers.

Composition of the multinutrient blocks: Six multinutrient blocks were made viz:Gliricidia + Urea multinutrient blocks (GUMNB), Gliricidia + Poultry manure Multi-nutrient blocks (GPMNB), Gliricidia + Urea + Poultry manure multi-nutrient blocks (GUPMNB), Leucaena + Urea Multi-nutrient blocks (LUMNB), Leucaena + Poultry Manure multi-nutrient blocks (LPMNB) and Leucaena + Urea + Poultry Manure Multi-nutrient blocks (LUPMNB), as described by Aye 2005,2007$)$.

Chemical Analysis: The block mixtures moulded were analysed for proximate, mineral and antinutrient and gross energy contents in triplicates using the method described in AOAC (1995). For the minerals, sodium and potassium were determined by flame photometry while phosphorus was determined by the vanadomolybdate method $(A O A C, 1980)$ using a corning colourimeters 253. Other minerals such as Calcium, Magnesium, Sulphur, Zinc, Iron, Copper, Manganese were determined after wet digestion with a mixture of nitric acid, sulphuric acid and perchloric acids using atomic spectrophotometry.

Determination of anti-nutrients: phytin, phytin-P, tannin and oxalate: For the quantification of phytin and phytin- $\mathrm{P}, 8 \mathrm{~g}$ portion of finely ground blocks were soaked in $200 \mathrm{~cm}^{3}$ of $2 \%$ hydrochloric acid and allowed to stand for 3 hours. The extract was then filtered through two layers of hardened filter paper. Fifty millimeters of the filtrate was pipetted in triplicate into $400 \mathrm{~cm}^{3}$ beakers before the addition of $10 \mathrm{~cm}^{3}$ $0.3 \%$ ammonium thiocyanate solution, as an indicator, and $107 \mathrm{~cm}^{3}$ of distilled water to obtain the appropriate acidity ( $\mathrm{pH} 4.5)$. The solution was then titrated with a standard ferric chloride solution containing $0.00195 \mathrm{~g} \mathrm{Fe} \mathrm{cm}^{3}$ to determine the amounts of phytin and phytin-P (Young and Greaves, 
1940). Where extracts were deeply coloured, they were decolourised with activated charcoal(Balogun and Fetuga, 1980).

For the determination of Tannin, $200 \mathrm{mg}$ of the samples in $10 \mathrm{~cm}^{3}$ of $70 \%$ aqueous acetone were extracted for $2 \mathrm{~h}$ at $30^{\circ} \mathrm{C}$ in a water bath using a GallenKamp orbital Shaker at 120/rpm. Fat was first removed from the samples by extracting with di-ethyl ether containing $1 \%$ acetic acid. Then the total polyphenols (as tannic equivalent) were determined as described by Makkar and Goodchild (1996).

Oxalate content was determined by the titrimetric method of Moir (1953) as modified by Obizoba and Awi (1991).

Determination of gross energy: The Gross energy of the dried samples were determined against thermochemical grade benzoic acid standard using GallenKamp ballistic bomb calorimeter.

Statistical Analysis: All values were means of triplicate determinations. Mean values for all parameters among blocks were assigned coefficient of variation (Steel and Torrie, 1980)

\section{RESULTS}

The proximate composition, hemicellulose, cellulose and gross energy constituents of the leaf residues are presented in Table1. The crude protein $(42 \pm$ $\left.0.7 \mathrm{~g} \mathrm{~kg}^{-1} \mathrm{DM}\right)$, ash (53 $\left.\pm 0.3 \mathrm{~g} \mathrm{~kg}^{-1} \mathrm{DM}\right)$ and ether extract $\left(101 \pm 0.2 \mathrm{~g} \mathrm{~kg}^{-1} \mathrm{DM}\right)$ of Gliricidia leaf residue were higher than those of Leucaena whereas, the hemicellulose of Leucaena fibre residue was higher at $70.2 \mathrm{~g} \mathrm{~kg}^{-1}$. The cellulose contents were 437.0 and $427.0 \mathrm{~g} \mathrm{~kg}^{-1}$ for Leucaena and Gliricidia fibres, respectively. The GE of Gliricidia (14.6 MJ kg-1) was higher than that of Leucaena $\left(10.1 \mathrm{MJ} \mathrm{kg}^{-1}\right)$.

Table 1: Proximate composition, fibre $\left(\mathrm{g} \mathrm{kg}^{-1} \mathrm{DM}\right)$ and gross energy contents ( $\mathrm{MJ} \mathrm{kg}^{-1}$ ) of leaf residues obtained from leaf protein concentrate fractionation.

\begin{tabular}{|l|l|l|l|}
\hline Composition & Leucaena & Gliricidia & CV\% \\
\hline DM & $934.2 \pm 0.1$ & $910.2 \pm 0.1$ & 1.8 \\
\hline CP & $40.2 \pm 0.6$ & $42.2 \pm 0.7$ & 3.4 \\
\hline Ash & $40.2 \pm 0.3$ & $53.1 \pm 0.3$ & 19.8 \\
\hline CF & $154.1 \pm 1.6$ & $221.0 \pm 1.2$ & 25.3 \\
\hline EE & $70.2 \pm 1.0$ & $101.2 \pm 0.2$ & 25.6 \\
\hline NFE & $696.0 \pm 1.0$ & $583.1 \pm 1.3$ & 12.5 \\
\hline Hemicellulose & 70.2 & 50.1 & 23.6 \\
\hline Cellulose & 437.0 & 427.0 & 1.6 \\
\hline GE (MJ kg & 10.1 & 14.6 & 5.8 \\
\hline
\end{tabular}

CV = Coefficient of Variation

NFE = Nitrogen free extract

$\mathrm{GE}=$ Gross energy

Table 2 shows that macro-mineral $P$ was the most abundant with values of 8333.3 and $5580.0 \mathrm{mg} 100 \mathrm{~g}^{-}$ ${ }^{1}$ for Gliricidia and Leucaena, respectively while Fe was the dominant micromineral at 83.9 and $38.2 \mathrm{mg}$ $100 \mathrm{~g}^{-1}$.

Table 2: Mineral Components of Leaf Residues (mg $\left.100 \mathrm{~g}^{-1}\right)$

\begin{tabular}{|l|l|l|l|l|l|l|l|l|l|l|}
\hline & Ca & Na & $\mathbf{K}$ & $\mathbf{P}$ & $\mathbf{M g}$ & $\mathbf{M n}$ & $\mathbf{F e}$ & $\mathbf{C u}$ & $\mathbf{Z n}$ & $\mathbf{N i}$ \\
\hline Leucaena & 234.8 & 392.9 & 237.1 & 5580.0 & 313.4 & 1.1 & 38.2 & 18.3 & 24.4 & 15.6 \\
\hline Gliricidia & 443.1 & 700.0 & 603.0 & 8333.3 & 540.0 & 12.0 & 83.9 & 9.2 & 62.8 & 19.8 \\
\hline CV & 41. & 39.7 & 61.6 & 28.0 & 37.6 & 117.7 & 52.9 & 46.8 & 62.3 & 16.8 \\
\hline
\end{tabular}

The anti-nutrients in the residues are phytin, phytin- $P$ and tannins (Table 3). Phytin and phytin-P were

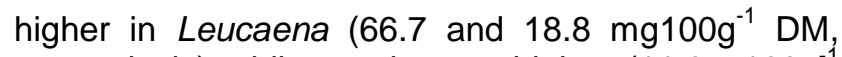
respectively) while tannin was higher $\left(11.0{\mathrm{~g} 100 \mathrm{~g}^{-1}}^{-1}\right.$ DM) in Gliricidia leaf residue.

Table 3: Phytin and Tannin Contents of Leaf Residues

\begin{tabular}{|l|l|l|l|}
\hline & $\begin{array}{l}\text { Phytin } \\
\mathbf{m g 1 0 0 9}^{-1}\end{array}$ & $\begin{array}{l}\text { Phytin-P } \\
\mathbf{m g 1 0 0 g}^{-1}\end{array}$ & $\begin{array}{l}\text { Tannin } \\
\mathbf{g 1 0 0 g}^{-1}\end{array}$ \\
\hline Leucaena & 66.7 & 18.8 & 8.6 \\
\hline Gliricidia & 22 & 6.0 & 11.0 \\
\hline CV & 71.3 & 73.0 & 17.3 \\
\hline
\end{tabular}


Proximate composition and energy content of multinutrient blocks (MNBs): Table 6 shows the crude protein (CP), ash, crude fibre (CF), ether extract(EE) and nitrogen free extract (NFE). CP (MNBs) ranged from $30.2 \pm 0.61 \mathrm{~g} \mathrm{~kg}^{-1} \mathrm{DM}$ in GPMNB to $344.2 \pm 1.19 \mathrm{~g} \mathrm{~kg}^{-1} \mathrm{DM}$ in GUMNB. The ash content varied from $28.6 \pm 0.01 \mathrm{~g} \mathrm{~kg}^{-1}$ DM in LPMNB to 333.1 $\pm 0.04 \mathrm{~g} \mathrm{~kg}^{-1} \mathrm{DM}$ in GPMNB, while the crude fibre ranged from $47.5 \pm 0.01 \mathrm{~g} \mathrm{~kg}^{-1}$ DM in LUMNB to 121.0 $\pm 0.03 \mathrm{~g} \mathrm{~kg}^{-1} \mathrm{DM}$ in GUPMMB. The ether extract (EE) ranged from $44.1 \pm 0.01 \mathrm{~g} \mathrm{~kg}^{-1} \mathrm{DM}$ in LUMNB to 91.1 $\pm 0.15 \mathrm{~g} \mathrm{~kg}^{-1}$ DM in GUPMMB The NFE varied from $247.2 \pm 1.16 \mathrm{~g} \mathrm{~kg}^{-1} \mathrm{DM}$ in GUMNB to $523.8 \pm 6.28 \mathrm{~g}$ $\mathrm{kg}^{-1} \mathrm{DM}$ in LPMMB.

The Gross energy (GE) contents of the multinutrient blocks ranged from $11.67 \mathrm{MJ} \mathrm{kg}^{-1}$ in GPMMB, to $15.48 \mathrm{MJ} \mathrm{kg}^{-1}$ in GUMNB. The GE values were lower in Leucaena-based MNBS than in Gliricidia-based MNBS.

Table 4: Ingredient composition (\%) of experimental multi-nutrient blocks

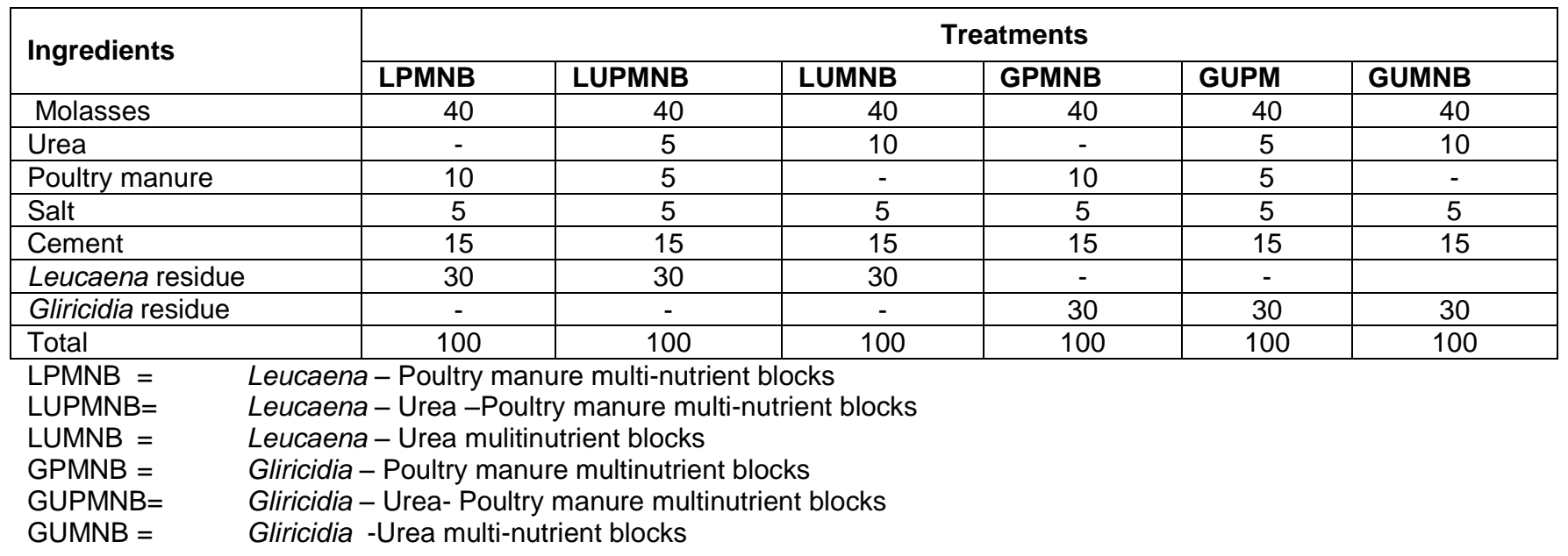

Table 5: Chemical composition of the major ingredients used in the multinutrient blocks $\left(\mathrm{g}^{\left.100 \mathrm{~g}^{-1}\right)}\right.$

\begin{tabular}{|l|l|l|l|l|}
\hline Ingredients & LLR & GLR & M & U \\
\hline Dry matter & 96.00 & 95.00 & 70.00 & 97.00 \\
\hline Nitrogen & 4.04 & 4.48 & 0.48 & 45.00 \\
\hline Ash & 7.98 & 8.12 & 0.62 & 0.01 \\
\hline Crude fibre & 11.56 & 10.22 & 0.28 & 0.02 \\
\hline Ether extract & 3.24 & 7.23 & 1.01 & 0.08 \\
\hline Nitrogen free Extract & 51.97 & 46.43 & 88.09 & ND \\
\hline
\end{tabular}

$\mathrm{LLR}=$ Leucaena leaf residue, GLR = Gliricidia leaf residue, $\mathrm{M}=$ Molasses, $\mathrm{U}=$ Urea, ND = Not detected.

Mineral constituents: The macro and micro-nutrient constituents of Leucaena and Gliricidia - based multinutrient blocks are presented in Table 7 . Calcium was the most abundant macro- nutrient and the values were higher in Leucaena-based MNBs while $\mathrm{Zn}$ and $\mathrm{Fe}$ were the most abundant micronutrients and $\mathrm{Cu}$ was the least abundant.

Anti-nutrients: The anti-nutrients in the MNBS are polyphenols (as tannic acid equivalent) which ranged

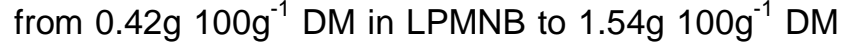
in GUPMNB, Phytin (Table8) varied from $4.42 \mathrm{~g} 100 \mathrm{~g}^{-}$

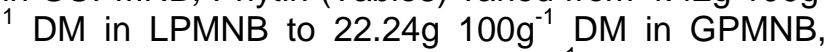

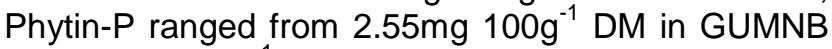

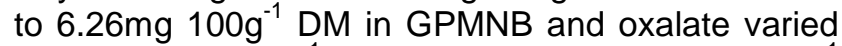

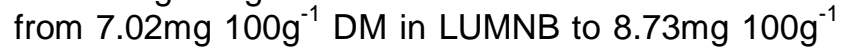
DM in GUMNB. 
Agric. Biol. J. N. Am., 2012, 3(5): 213-220

Table 6 : Proximate composition ( $\mathrm{g} \mathrm{kg}^{-1}$ ), Gross energy (MJ kg${ }^{-1}$ ) and strength of multinutrient blocks

\begin{tabular}{|c|c|c|c|c|c|c|c|c|}
\hline Treatment & DM & $\mathrm{CP}$ & CF & EE & ASH & NFE & $\begin{array}{l}\text { Gross } \\
\text { energy }\end{array}$ & Strength \\
\hline LPMNB & $784.5 \pm 0.03$ & $54.4 \pm 0.59$ & $66.0 \pm 071$ & $\begin{array}{r}70.2 \\
+0.01\end{array}$ & $28.56 \pm 0.01$ & $523.8 \pm 6.28$ & 12.74 & Strong \\
\hline LUPMNB & $\begin{array}{c}754.8 \pm \\
0.01\end{array}$ & $195.7 \pm 1.19$ & $48.5 \pm 0.42$ & $\begin{array}{c}72.3 \\
+0.02\end{array}$ & $248.4 \pm 0.2$ & $414.1 \pm 0.49$ & 13.58 & Strong \\
\hline LUMNB & $769.7 \pm 0.04$ & $\begin{array}{c}328.2 \pm \\
0.61\end{array}$ & $47.5 \pm 0.01$ & $\begin{array}{l}44.1 \pm \\
0.01\end{array}$ & $248.4 \pm 0.3$ & $\begin{array}{c}33 \\
1.8 \pm 0.38\end{array}$ & 15.33 & $\begin{array}{l}\text { Very } \\
\text { strong }\end{array}$ \\
\hline GPMNB & $\begin{array}{c}785.6 \pm \\
0.01\end{array}$ & $30.2 \pm 0.61$ & $70.3 \pm 0.01$ & $\begin{array}{c}81.9 \\
\pm 0.01\end{array}$ & $333.1 \pm 0.04$ & $484.5 \pm 0.57$ & 11.67 & Strong \\
\hline GUPMNB & $711.8 \pm 0.01$ & $\begin{array}{c}179.0 \pm \\
1.20\end{array}$ & $121.0 \pm 0.03$ & $91.1 \pm 0.15$ & $284.9 \pm 0.05$ & $324.0 \pm 0.98$ & 14.56 & Strong \\
\hline GUMNB & $\begin{array}{l}765.6 \\
\pm 0.02\end{array}$ & $\begin{array}{c}344.2 \pm \\
1.19\end{array}$ & $77.4 \pm 0.04$ & $\begin{array}{c}65.1 \pm \\
0.01\end{array}$ & $266.0 \pm 0.04$ & $247.2 \pm 1.16$ & 15.48 & $\begin{array}{l}\text { Very } \\
\text { strong }\end{array}$ \\
\hline MEAN & $\overline{7} 62.0$ & 188.6 & 71.8 & 70.8 & 281.2 & 387.6 & 13.89 & \\
\hline S.D & 2.72 & 13.19 & 2.69 & 1.60 & 2.89 & 10.53 & 1.51 & \\
\hline CV & 3.57 & 69.94 & 37.47 & 22.60 & 10.28 & 27.17 & 10.87 & \\
\hline
\end{tabular}

$\mathrm{DM}=$ Dry matter, $\mathrm{CP}=$ Crude protein, $\mathrm{CF}=$ Crude fibre, $\mathrm{EE}=\mathrm{Ether}$ extract, $\mathrm{NFE}=$ Nitrogen free extractives

$\mathrm{SD}=$ Standard deviation, $\mathrm{CV}=$ Coefficient of Variation.

Table 7: Mineral constituents of experimental multinutrient blocks $\left(\mathrm{mg} \mathrm{kg}^{-1}\right)$

\begin{tabular}{|c|c|c|c|c|c|c|c|c|c|c|}
\hline & $\mathrm{Na}$ & $\mathbf{P}$ & K & $\mathbf{C a}$ & Mg & $\mathbf{S}$ & $Z \mathbf{n}$ & $\mathrm{Fe}$ & $\mathrm{Cu}$ & Mn \\
\hline LPMNB & 648.20 & 210.70 & 623.30 & 971.40 & 135.70 & 121.43 & 214.20 & 57.10 & ND & 21.40 \\
\hline LCUPMNB & 635.40 & 107.10 & 628.50 & 950.00 & 121.40 & 62.50 & 357.10 & 85.70 & ND & 14.30 \\
\hline LUMNB & 432.30 & 215.60 & 563.20 & 737.50 & 225.00 & 45.31 & 131.30 & 68.80 & 0.06 & 21.80 \\
\hline GPMNB & 873.50 & 162.50 & 923.20 & 766.70 & 166.70 & 141.67 & 258.30 & 158.30 & 0.08 & 50.00 \\
\hline GUPMNB & 771.40 & 71.40 & 831.00 & 892.90 & 142.90 & 51.79 & 414.30 & 264.30 & ND & 42.90 \\
\hline GUMNB & 642.10 & 35.40 & 663.50 & 757.10 & 192.90 & 121.43 & 171.40 & 257.10 & ND & 57.00 \\
\hline MEAN & 667.20 & 133.8 & 705.50 & 845.90 & 164.10 & 90.68 & 257.80 & $14 s 8.60$ & 0.07 & 34.60 \\
\hline SD & 148.70 & 74.45 & 139.89 & 104.60 & 39.10 & 42.10 & 109.30 & 93.80 & 0.00 & 17.70 \\
\hline CV & 22.30 & 55.60 & 19.80 & 12.40 & 23.80 & 46.4 & 42.40 & 63.10 & 20.20 & 51.0 \\
\hline ND & & ted & & & & & & & & \\
\hline SD & & Devia & & & & & & & & \\
\hline
\end{tabular}

Table8: Anti- nutrients of experimental multinutrient Blocks

\begin{tabular}{|c|c|c|c|c|}
\hline Treatment & $\begin{array}{l}\text { Tannin } \\
\text { g100g }^{-1}\end{array}$ & 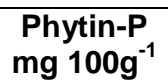 & $\begin{array}{c}\text { Phytate } \\
\mathrm{mg} \mathrm{100g}^{-1}\end{array}$ & $\begin{array}{c}\text { Oxalate } \\
{\mathrm{mg} 100 \mathrm{~g}^{-1}}\end{array}$ \\
\hline $\begin{array}{l}\text { LPMNB } \\
\text { LUPMNB } \\
\text { LUMNB } \\
\text { GPMNB } \\
\text { GUPMNB } \\
\text { GUMNB } \\
\text { MEAN } \\
\text { SD } \\
\text { CV }\end{array}$ & $\begin{array}{l}0.42 \\
0.49 \\
1.37 \\
0.44 \\
1.54 \\
0.63 \\
0.82 \\
0.50 \\
60.98\end{array}$ & $\begin{array}{l}6.03 \\
3.25 \\
2.78 \\
6.26 \\
3.94 \\
2.55 \\
4.14 \\
1.63 \\
39.37\end{array}$ & $\begin{array}{c}4.42 \\
11.53 \\
9.88 \\
22.24 \\
14.00 \\
9.06 \\
14.69 \\
5.79 \\
39.41\end{array}$ & $\begin{array}{l}7.65 \\
7.02 \\
7.74 \\
7.56 \\
7.83 \\
8.73 \\
7.76 \\
0.56 \\
7.22\end{array}$ \\
\hline
\end{tabular}




\section{DISCUSSION}

From the proximate, hemicellulose, cellulose and mineral components, the residues have low nutritional values. However, since it is possible to enhance nutritional value through the activities of rumen micro organisms which further break down the fibre and converts some to microbial protein (Agbede and Aletor, 2003b) which will be utilized by the animal in their abomasum. Also, volatile fatty acids produced from the degradation of these residues will contribute to meeting the energy requirements of the animals. Therefore, despite the low nutritive values of these residues, their incorporation with Urea or poultry manure in multinutrient blocks will enhance their use as feed supplements for ruminants especially during extended dry season.

The phytin and tannin contents of the leaf residues were very low, suggesting that when fed to ruminants either wholly or inform of multinutrients, they will not pose serious health hazards. This is more so as ruminants utilize these anti-nutritional factors through the activities of the micro fauna and flora in their rumen. Nutritional studies have shown that phytic acid is a chelating agent for divalent cations $(\mathrm{Ca}, \mathrm{Mg}$, $\mathrm{Fe}$ and $\mathrm{Zn}$ ) and consequently interferes with mineral bio-availability (Savage, 1988). Tannins may not always be anti-nutritional in ruminants as they may enhance amino acids absorption in the small intestine (Barry and McNabb, 2002) via a "by-pass process" (Aletor and Fasuyi, 1997).

The proximate composition, energy, mineral and antinutritional constituents of the MNBs reveal their potential as sources of feed for ruminants. For instance, the DM content $\left(711.8-785.6 \mathrm{~g} \mathrm{~kg}^{-1}\right)$ was quite high showing the reasonable extent of drying, and look adequate since the blocks would serve as supplements to other conventional feeding-stuffs like cassava peel and grass. Urea and poultry manure release ammonia very rapidly while the Nitrogen free extractives reflect the energy/carbohydrate content of the blocks and these are in relation to the molasses content. Thus, MNBs produced from the raw materials would give reasonable levels of available energy and nitrogen when used in animal feeding trials. The crude protein content of the LUPMNB, LUMNB, GUPMNB and GUMNB $179.0-344.2 \mathrm{~g} \mathrm{Kg}^{-1}$ DM compared favourably with and even surpassed 117.4 - $144.8 \mathrm{~g} \mathrm{Kg}^{-1} \mathrm{DM}$ reported for urea- molasses blocks (Onwuka, 1999). This study further confirms the ability of the fractionation scheme to enhance the protein and energy contents of the multi-nutrient blocks owing to its ability to remove the non-protein components of the Leucaena and Gliricidia leaves with attendant concentration of the protein and energy.

The high energy content $\left(11.67-15.48 \mathrm{MJ} \mathrm{kg}^{-1}\right)$ with low crude fibre (47.5-121.0 $\left.\mathrm{g} \mathrm{kg}^{-}{ }^{1} \mathrm{DM}\right)$ of the multinutrient block clearly suggests that they could serve as alternative feed resources for ruminants. (Hendratno, 1997; Onwuka 1999)

The study also shows that the Gliricidia and Leucaena-based MNBs contained some valuable mineral elements. $\mathrm{K}, \mathrm{Na}, \mathrm{Ca}, \mathrm{Mg}, \mathrm{P}$ and $\mathrm{Zn}$ contents of the MNBs were particularly high when compared with most other foods (Leng et al., 1991) while Fe which is commonly deficient in many diets, is fairly abundant particularly in the Gliricidia-based MNBs. The high proportions of mineral elements in these blocks when compared with other conventional foods such as legumes and tubers, confirm their importance as rich sources of minerals.

It is a common knowledge that leguminous plants such as Gliricidia sepium and Leucaena leucocephala have a high potential to meet dietary protein requirements of animals, but their inherent ability to synthesise a myriad of anti-physiological factors remains a primary drawback to their direct use as food for animals. This study shows that Leucaena and Gliricidia - based MNBs contain phytin, phytin-P, total phenol and oxalate which varied with the residues from the plant species. It is evident that fractionation reduced the anti-nutrients, suggesting that the nutritive qualities of the blocks could be enhanced by fractionation scheme (Oke, 1973; Agbede and Aletor, 2004; Agbede, 2006; Aye, 2007).

The consistency observed in the block mixtures indicate the need for pre-mixing the cement in water before adding to the mixture (Sansoucy, 1986; Sansoucy and Aarts, 1986; Mwendia and Khasatsili, 1990; Onwuka 1999; Aye, 2007). This facilitates even spread of the cement in the block and its uniform hardening. The MNBs made were strong i.e. they did not crumble and were therefore not crushed. This has the advantage of ensuring gradual release of urea or poultry manure and molasses to animals when they are fed such feed blocks. If otherwise, urea or poultry manure and molasses toxicity will occur, as observed by Preston and Leng (1990) and Onwuka (1997). When soaked in water the blocks did not dissolve up till the fourth day similar to five days observed by Onwuka (1999). The implication is that ruminant saliva would not soak the blocks, 
unnecessarily dissolve the nutrients thereby leading to over-supply of urea, poultry manure or molasses to the animals.

The blocks used 6 to 7 days to harden and did not grow mouldy even when stored for three months. Thus blocks prepared during the dry season can be used up till the middle of the next raining season, when feed would be readily available to the ruminants. The blocks were air-dried which implies that in the rural areas where goats and sheep are free roaming, the blocks can be better protected from being crushed or smashed when dried in shades away from these scavengers (Sudana and Leng, 1996)

\section{CONCLUSION}

The use of fibrous residues from leaves of Leucaena and Gliricidia as supplements for ruminants either wholly or in a form enriched with poultry manure or urea represents an appropriate nutritional intervention strategy especially during the extended dry season.

Similarly, these multinutrient blocks are potential sources of readily available energy and nitrogen which would fill the gap in feed availability to ruminants during the dry season months of November through April. The use of blocks as feed support system in the rural areas will ensure that the animals are not just being maintained but can be sustained for productive performance. The ease of preparation and maintenance make the blocks technologies practicable for adoption by rural smallscale farmers.

Thus, feeding of the multinutrient blocks represents a strategic supplement for ruminants in South Western Nigeria.

\section{REFERENCES}

Adegbola, T. A. (2002) Nutrient intake, digestibility and rumen metabolites in bulls fed rice straw with or without supplements. Nig. J. Anim. Prod. 29(1) 40-46.

Agbede, J. O. (2006) Characterization of leaf meals, protein concentration and residues from some tropical leguminous plants. J. Sci. Food Agric 86:22-82.

Agbede, J. O. and Aletor, V. A. (2003) Evaluation of fish meal replaced with leaf protein concentrate from Gliricidia in diets for broiler-chicks. Effect on performance, muscle growth and haematology and serum metabolites. International Journal of Poultry Science 2(4):242-250.

Agbede, J. O. and Aletor, V. A. (2004) Chemical Characterization and protein quality evaluation of leaf protein concentration from Gliricidia sepium and Leucaena leucocephala. J. Food Sci. Technol 39:253261.

Aletor, V. A. (1993b) Cyanide in gari 2. An assessment of some aspects of the nutrition, biochemistry and haematology of the rat fed gari containing varying residual cyanide levels. Inter. J. Food Sci. 44: 289-295.

Aletor, V. A. and Fasuyi, A. O. (1997) Nutrient Composition and Processing effects on cassava leaf (Manihot esculenta Crautz) anti-nutrients. In: Ologbobo A. O.; lyayi E. A. (eds.) Proceedings of the Second Annual Conference of Animal Science Assoc. of Nigeria. September 16-17. Lagos pp 231-242.

Aletor, O; Evivie, S. E and Aletor, V. A(2010) A comparative study of the nutritive characteristics, functional properties and in vitro protein digestibility of fish meal and some unconventional protein concentrates. Journal of sustainable Technology $1(1): 67-75$.

AOAC (1980) Official Method of Analysis 10th edition. Association of Officiating Analytical Chemist. Washington DC.

AOAC (1995) Official Methods of Analysis. 16th edn. (Association of Official Analytical Chemists Arlington, VA)

Aye, P. A.(2005) Development of multinutrient blocks for the small ruminants in Nigeria. Proceedings 10th Annual ASAN Conference Sept. 12-15 2005. pp 195196.

Aye, P. A(2007) Production of multinutrient blocks for ruminants and alcohol from the waste products of leucaena and gliricidia leaves using local technologies. Ph.D Thesis. Federal University of Technology, Akure, Nigeria.

Balogun, A. M. and Fatuga, B. L. (1980) Tannin, Phytin and Oxalate Content of some wild under-utilized crop seeds in Nigeria. Food Chem. 30:37-43.

Fajemisin, A.N; Fadiyimu, A. A and Alokan, J. A (2010) Nutrients digestibility and performance of West African dwarf sheep fed dietary inclusion of sundried or fermented rumen digesta and poultry droppings. Journal of Sustainable Technology 1(1):76- 84.

FAO (1990) Guidelines for the manufacture and utilization of molasses-urea blocks. FAO of the United National Rome, Italy, August 1990.

FAO (1990) Utilization of tropical foods. Food and Nutrition Paper 47/1 Rome, Italy.

Fellows P. (1987) Village-Scale leaf fractionation in Ghana. Trop. Sci. 27, 77-84.

Hadjipanayiotou, M.; Verhaeghe, L.; Allen, M.; Kronfoleh, A. R.; Labban, L. M.; Shurbaji, A.; Al-Wadi, M.; Dassouki, M.; Shaker, B. and Amin, M. (1993) Urea 
blocks. I. Methodology of block making and different formulae tested in Syria. Livestock Research for Rural Development 5(3).

Hassoun, P. (1989) Manufacture of urea blocks without molasses. Mimeograph, FAO, Rome, Italy.

Hendratno, C. (1997) Development and utilization of UMMB as a feed supplement for ruminants. Paper Presented at the first regional training workshop (AFRA) on guidelines for developing supplementation packages. Morocco. March 1997.

ILCA (1986) International livestock Centre for Africa. Annual Livestock Production in the Sub-humid Zone of West Africa. A regional review. Addis Ababa, Ethiopia.

Kunju, P. J. G. (1986) Urea-Molasses block lick, a feed supplement for Ruminants. Rice straw and related feeds in Ruminant Rations. Proc. Int. Workshop, kandy, Sri Lanka pp 261-274.

Leng, R. A.; Preston T. R.; Sansoucy R. and George Kunju P. L.(1991) Multinutrient blocks as a strategic supplement for ruminants. World Animal Review 67:11-19.

Leng, R.A and Kunju, G. (1989) Supplementation practices for milking cattle and buffaloes in India. Report to National Dairy Development Board, Anand. India. Pp 31-40.

Makkar, A. O. S. and Goodchild A. V. (1996) Qualification of tannins: A laboratory manual. International Centre for Agriculture Research in the Dry Areas (ICARDA) Aleppo, Syria iv + 25 pp.

Mancini, V. P.; Lebzein P.; Reinhardt R. and Flachowsky W. (1997) Studies on the influence of differently treated Molasses/Urea mixts. Vs Soyabean meal on parameters of rumen fermentation, duodenal nutrient flow and in sacco degradation of maize silage and wheat straw in non-lactating dairy cows. Anim. Res. and Dev. 46:75-86.

Moir, R. J. (1953) Nitrogen metabolism in ruminant digestion. Aust. Vet. J. 23:287-291.

Mwendia, C. W. and Khasotsili (1990) Molasses energy blocks for beef cattle. In: Dzowela B. H.; Said A. N; Wendern-Agenehu and Kategile J. A. (eds.) Proceedings of PANESA/ARNAB workshop. Malawi ILCA, Ethiopia pp. 389-403.
Obizoba, I.C and Awi, J.V (1991) Effect of soaking, sprouting, fermentation and cooking on the nutrient composition and some antinutritional factors of Sorghum guinensis seeds. PI. Fd. Hum. Nutr. 41: 203.

Oke, O. L. (1973) Leaf Protein Research in Nigeria: a review. Trop. Sci. 15(2) 139-155.

Onwuka, C.F.I. (1997) Plant Phytates and Oxalates and their effects on nutrient utilization by goats. Nig. Journal of Anim. Prod. 23 (1) 53-60.

Onwuka, C. F. I. (1999) Molasses blocks as supplementary feed resources for ruminants. Arch. Zootech 48:89-94.

Pickstock, M. (1985) Molasses as drought feed for livestock. Agric. Sci. Digest (M. E), 8:3.

Preston, T. R. and Leng, R. A. (1987) Matching ruminant production systems with available resources in the tropics and sub-tropics. Penambul books, Armidale pp 24-25.

Preston, T. R. and Leng, R. A. (1990) Matching ruminant production systems with available resources in the tropics and sub-tropics, CTA, Netherlands.

Sansoucy, R. (1986) The Sahel: manufacture of molassesurea blocks. World Anim. Review 57:40-48.

Sansoucy, R. (1996) New developments in the manufacture and utilization of multinutrient blocks. WAR/RMZ 82: 78-83.

Sansoucy, R. and Aarts, G. (1986) Molasses-urea blocks as multinutrient supplement for ruminants. Proc. FAO Expert Consultation on Sugar Cane as Feed. Santo Domingo, Dominican Republic, July 1986, Rome. FAO.

Savage, G. P. (1988): The composition and nutritive value of Lentils (Leusculinaris). Nutr. Abstr. And Reviews (Series A) C. A. B. International vol 58(5)319-348.

Steel, R. G. B. and Torrie, J. H. (1980) Principle and procedures of statistics. McGraw Hill book Co. N.Y.

Sudana, L. B. and Leng, R. A. (1996) Effects of supplementing a wheat straw diet with urea or a ureamolasses blocks and/or cotton seed meal on intake and liveweight change of lambs. Anim. Feed. Sci. and Technol. 16:15-35. 